\title{
Conversion of properties of typical black earth at irrigating by waters of different quality
}

\section{Vorotyntseva,}

Candidate of Agricultural Sciences

National Scientific Center «Institute for Soil Science and Agrochemistry Research named after

\section{O.N. Sokolovsky»}

The purpose. To study influence of irrigating by waters of different quality on directedness of edaphic processes and conversion of properties of typical black earth of Northern Steppe. Methods. Field, analytical, statistical. Results. Trends and directions are fixed of changes in physical, physical and chemical, chemical properties of typical black earth at irrigating by suitable, restrictedly suitable and unsuitable waters which consist in change of salt, mineralogical, granulometric composition, content of the absorbed cations, content of humus. Conclusions. With decrease of quality of irrigating water there is magnification of salinization, alcalination, seal, charging of granulometric composition, lowering of resistance of microscopic structure and content of water-resisting assembly units. That requires supervisory control of their properties for the warning of aggravation of soil-meliorative state and development of degradation processes.

Key words: typical black earth, salinization, alcalination, irrigating, conversion, irrigating water, properties.

Formulation of the problem. Irrigation of lands in areas of low and unstable humidity is one of the leading factors of intensification, sustainable development of agricultural production and obtaining stable yields of cultivated crops to ensure food security. In recent years, given the increase in aridity of climate and the increase in air temperature during the growing season, its role is greatly enhanced. So restoration of irrigation potential by simultaneous using efficiency of irrigated lands and its further development are the priority tasks for development of agrarian sector of Ukraine [1].

The International Commission on Irrigation and Drainage (ICID) coordinates Global trends of amelioration and water management. One of its tasks is to increase receiving food in the world and to increase productivity of reclaimed lands [2, 3]. According to ICID and FAO (2011), for the past 50 years it has been marked growth dynamics in irrigated lands in the world.

Irrigated lands are the anthropogenic transformed natural systems, in which under the influence of irrigation there is a complex transformation of the composition and properties, changes in direction and intensity of the evolution of soil that are determined by the quality of irrigation water, climatic and hydrogeological conditions in the region, relief, initial soil properties, irrigation technology, and crop farming. With the changing landscape, soil and environmental conditions on the arrays of irrigation there are activated both the fleeting soil formation processes and lasting soil formation processes of characteristics and properties [4, 5]. Evolution of soils can be developed both by conserving properties and by degradation processes that determine their ability to perform their biosphere, environmental and social functions [4, 6-8].

Purpose of research - the study of the influence of irrigation with different water quality on soil processes orientation and transformation of properties of chernozem ordinary of northern Steppe of Ukraine in order to justify measures for the protection, rational use of lands and the possibility of restoring the irrigation areas.

Research methodology. The basis of the research was carrying out of a comprehensive monitoring environmental and land survey of lands in Donetsk region during 1997-2013, laying fixed monitoring sites using the comparative method key-analogs according to existing methods [9]. 
Assessment of changes in the physical, physical-chemical and chemical properties of soils in irrigated and unirrigated conditions (by irrigation with suitable, limited suitable and unsuitable waters) was performed on three typical fixed monitoring sites in the system "irrigation water - soil - crop".

The site №1 was placed in the Slavyansk district (LLC "TECHNOTRADE LTD", v. Nikolske), irrigation was carried out with sprinkling by machinery BAUER with suitable water of class 1 from channel Siversky Donets-Donbass (Table 1). The site № 2 was placed in the urban area of Donetsk (LLC "Teplychny", v. Larina), irrigation was carried out with limited suitable water of class 2 by agronomic and ecological criteria [10-11] from r. Kalmius.

The site №3 was placed in Maryinsky district (AF named after Gorky, v. Dachne), there was used for irrigation unsuitable for irrigation water of class 3 . Soil of research was represented by chernozem ordinary low humus hard loamy and light clay size distribution on loess loam. The studied area was in automorphic conditions with level of ground water more than $5 \mathrm{~m}$ from the surface. The term of irrigation was about $45-50$ years.

Chemical composition of irrigation water, 2013.

\begin{tabular}{|c|c|c|c|c|c|c|c|c|c|}
\hline \multirow{2}{*}{\multicolumn{2}{|c|}{\begin{tabular}{|l|l} 
Amount of \\
salt, \\
$\mathrm{g} / \mathrm{dm}^{3}$
\end{tabular}}} & \multicolumn{6}{|c|}{ Content of ions $\mathrm{m}-\mathrm{Eq} / \mathrm{dm}^{3}$} & \multicolumn{2}{|c|}{$\begin{array}{l}\text { |rrigation assessment } \\
\text { by danger }\end{array}$} \\
\hline & & $\mathrm{HCO}_{3}^{-}$ & $\mathrm{Cl}^{-}$ & $\mathrm{SO}_{4}{ }^{-2}$ & $\mathrm{Ca}^{2+}$ & $\mathrm{Mg}^{2+}$ & $\mathrm{Na}^{+}+\mathrm{K}^{+}$ & salinizatio & solonetsizatio alkalinizatio \\
\hline \multicolumn{10}{|c|}{ Siversky Donets-Donbass channel } \\
\hline 0,6 & 7,8 & 2,0 & 2,6 & 3,9 & 2,0 & 2,3 & 4,2 & class 1 & class1 \\
\hline \multicolumn{10}{|c|}{ r. Kalmus } \\
\hline 2,2 & 7,8 & 6,5 & 9,7 & 16,8 & 4,5 & 7,9 & 15,6 & class 2 & class 2 \\
\hline \multicolumn{10}{|c|}{ Kurahivske water reservoir } \\
\hline 2,9 & 8,1 & 4,2 & 13,6 & 29,3 & 7,3 & 10,4 & 29,4 & class 2 & class 2 \\
\hline \multicolumn{9}{|c|}{ Content of heavy metals, $\mathrm{mg} / \mathrm{dm}^{3}$} & \multirow[b]{2}{*}{$\begin{array}{l}\text { Irrigation assessment on } \\
\text { environmental criteria }\end{array}$} \\
\hline $\mathrm{Zn}$ & $\mathrm{Mn}$ & $\mathrm{Fe}$ & $\mathrm{Cu}$ & $\mathrm{Ni}$ & Co & $\mathrm{Pb}$ & $\mathrm{Cd}$ & $\mathrm{Cr}$ & \\
\hline \multicolumn{10}{|c|}{ Siversky Donets-Donbass channel } \\
\hline 0,018 & 0,007 & 0,015 & 0,005 & 0,006 & 0,004 & 0,018 & 0 & 0,003 & class1 \\
\hline \multicolumn{10}{|c|}{ r. Kalmus } \\
\hline 0,006 & 0,038 & 0,048 & 0,005 & 0,039 & 0,034 & 0,048 & 0,006 & 0,004 & class 2 by $\mathrm{Pb}, \mathrm{Cd}, \mathrm{Co}$ \\
\hline \multicolumn{10}{|c|}{ Kurahivske water reservoir } \\
\hline 0,007 & 0,059 & 0,123 & 0,004 & 0,058 & 0,055 & 0,065 & 0,009 & 0,009 & $\begin{array}{l}\text { class } 3 \text { by } \mathrm{Pb}, \mathrm{Co}, \\
\text { class } 2 \text { by } \mathrm{Cd}\end{array}$ \\
\hline
\end{tabular}

On each side there were placed the soil sections and wells for studying morphological structure of profile and agrophysical, physical-chemical and chemical properties of chernozem ordinary: density of soil compilation, soil particle size and micro aggregate composition, salt composition, contents of absorbed cations, calcium carbonate, humus, activity of $\mathrm{Ca}^{2+}$ and $\mathrm{Na}^{+}$, mineralogical composition, carried out on standardized and certified methods.

Research results. Research has established that irrigation causes significant changes in direction of the natural soil processes, modes and associated with them parameters of morphological structure type, 
composition and properties of chernozem ordinary, one of the prominent factors of which is chemical composition of irrigation water.

It was established that under prolonged irrigation with limited suitable and unsuitable water in the morphological structure of soil profile it was visualized irrigation alkalinity of horizons $\mathrm{He}$ and $\mathrm{Hi}$, available glossiness on the facets of structural units, there was a compaction of humus- illuvial horizon, change lumpy, granular structure on the lumpy-silty (arable layer, horizon $\mathrm{He}$ ) and lumpy-prismatic (subsoil layer, horizon $\mathrm{Hi}$ ). Profile of irrigated soils compared with unirrigated analogue is different more humusaccumulative horizon due to improved water regime and the creation of favorable conditions for plant development, deeper effervescence line from $\mathrm{HCl}$ and depth of carbonate horizon with white soft spot, indicating calcium leaching by irrigation water.

It was determined that by the irrigation there is activation of halo-chemical processes that lead to the transformation of cation-anion composition of salts, changing their chemistry such as salinity, defined mainly by chemical composition of irrigation water. In soil of LLC "Technotrade LTD" by irrigation with fresh water compared to the unirrigated analogue it is observed some tendency to increase the content of soluble sodium and reduction of calcium on the profile of the soil (Fig. 1), resulting in a ratio of $\mathrm{Ca}: \mathrm{Na}$ over a long period irrigation has changed from 16 10: 1 to 3.8: 1 . There was leaching salts in 0-100 cm layer of chernozem ordinary, and their content was $0,06-0,07 \%$, including toxic $-0,03-0,05 \%$. The soil by the content of toxic salts is classified as nonsaline one. Salt in multi-mode dynamics is characterized by seasonally-reverse cycle without accumulation of salts to levels that determine the classification changes.

In LLC "Teplychny" by irrigation of chernozem ordinary with mineralized water $\left(2.2 \mathrm{mg} / \mathrm{dm}^{3}\right)$ the content of general and toxic salts in the aqueous extract (0-100 cm layer) was increased to $0,10-0,15 \%$ and $0,06-0-10 \%$ respectively, mainly due to chlorides and sulfates of sodium and magnesium. Under the influence of irrigation there is leaching salts by soil profile by forming horizon of their accumulation at a depth of $50-75 \mathrm{~cm}$, which is determined by the intensity of watering and irrigation norm during the growing season.

Salinization of top layer 0-50 cm at a level below low level and only in layers $50-75 \mathrm{~cm}$ and $75-100 \mathrm{~cm}$ was increased to gradation of weak one. In multi-dynamics it was observed seasonally-reverse migrationaccumulation of salts with a tendency to strengthen of halogen processes and salinity in summer and desalinization - in autumn and winter.

There is a raising alkalinity by the soil profile: water $\mathrm{pH}$ is increased from 7.6 to 7.9 . Value of soluble $\mathrm{Ca}: \mathrm{Na}$ in the topsoil is decreased from 10.0: 1 to $0.9: 1$, which shows the process development of irrigation alkalinity.

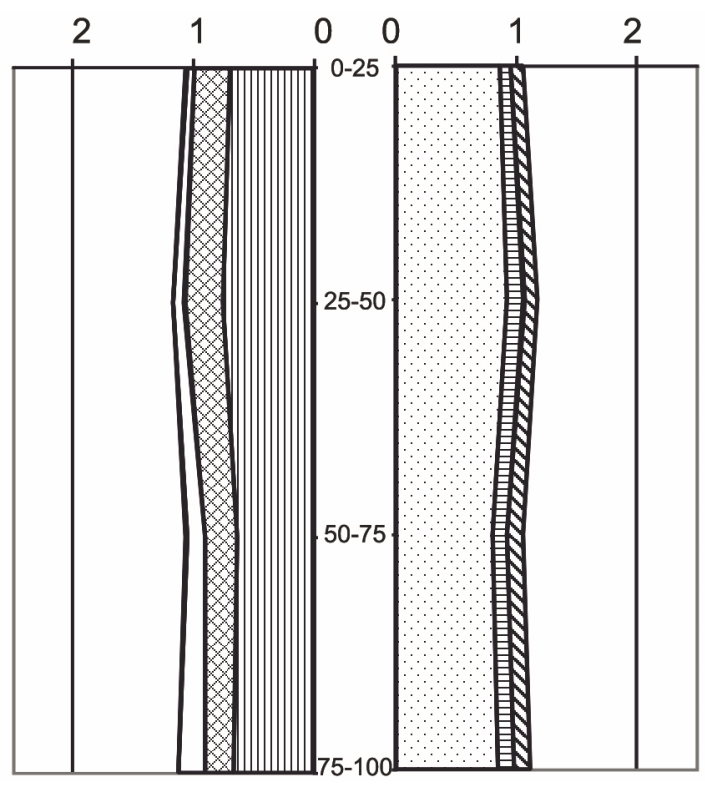

a) unirrigated soil

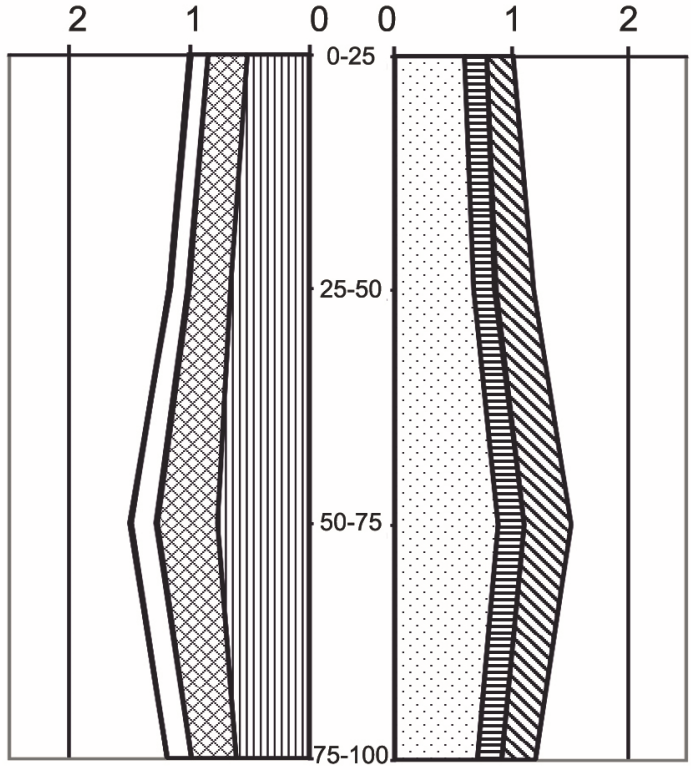

b) Irrigation by water of class 1 


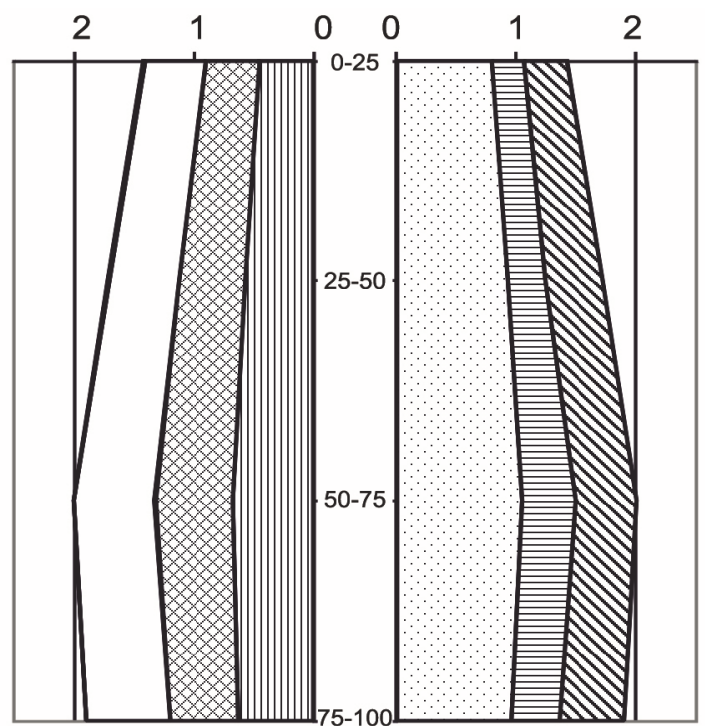

c) Irrigation by water of class 2

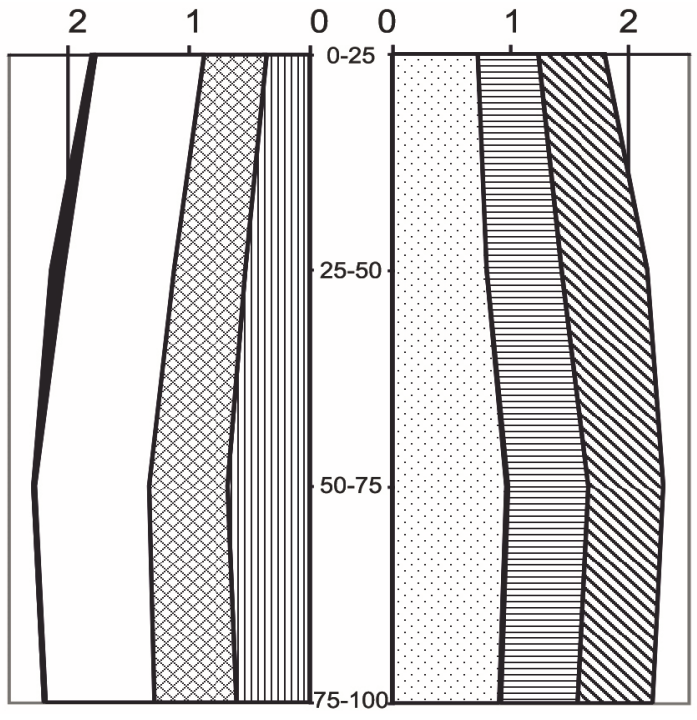

d) Irrigation by water of class 3

Figure - The profile distribution of water-soluble salts (mg-Eq / $100 \mathrm{~g}$ soil) in irrigated and unirrigated chernozem ordinary

With increasing salinity of irrigation water to $2.9 \mathrm{mg} / \mathrm{dm}^{3}$ (Agrofirma named after Gorky) the degree of transformation of the cationic-anionic composition of aqueous extract is increased compared to the previous subject of studies by greater increase in the content of chlorides, sulfates, water soluble sodium and reducing the concentration of soluble calcium. Content of toxic soluble salts is rised to $0,10-0,12 \%$, that by chloride-sulfate type corresponds to the low level of salinity. Value Ca:Na by the profile is changed from 2.8:1 to $0.5-0.9: 1$, indicating the alkalinity of the soil profile of chernozem ordinary. Under the influence of irrigation in the soil of all research objects there is changing its carbonate regime consisting of calcium carbonate leaching in the lower horizons with accumulation in the layer $75-100 \mathrm{~cm}$ (at the level of $16,0-20,2 \%)$. In unirrigated soil their concentration rises to $5-12 \%$ in the layer of subsoil $25-50 \mathrm{~cm}$.

Changes in ion-salt composition of water extraction lead to restructuring the composition of the soil absorbing complex (SAC). Under freshwater irrigation of class 1 (Fig. 2) in the $0-50 \mathrm{~cm}$ layer it is observed a slight decrease in absolute and relative content of absorbed calcium (from $77 \%$ to $73 \%$ from the amount of absorbed cations) and increasing the proportion of absorbed sodium (from $0.4 \%$ to $0.7 \%$ ) and magnesium (from $21.5 \%$ to $25 \%$ ). Arable layer is characterized as non-solonetzic (the proportion of sodium and potassium from the amount of absorbed cations $1.8 \%$ ).

In terms of irrigation by water with increased mineralization processes of SAC transforming are more intense, and the degree of manifestation of degradation processes is higher.

In LLC "Teplychny" by irrigation of chernozem ordinary by water with a salinity of $2.2 \mathrm{mg} / \mathrm{dm}^{3}$ compared with unirrigated analogue there is growing saturation of absorbing complex with sodium and magnesium from $0.5 \%$ to $1.6 \%$ and from $18.1 \%$ to $23.0 \%$ respectively, resulting in a degree of alkalinity has low degree ( $3.4 \%$ sodium and potassium from the amount of absorbed cations). As a result of longterm irrigation the share of absorbed calcium was decreased by $3,5-5,0 \%$. 


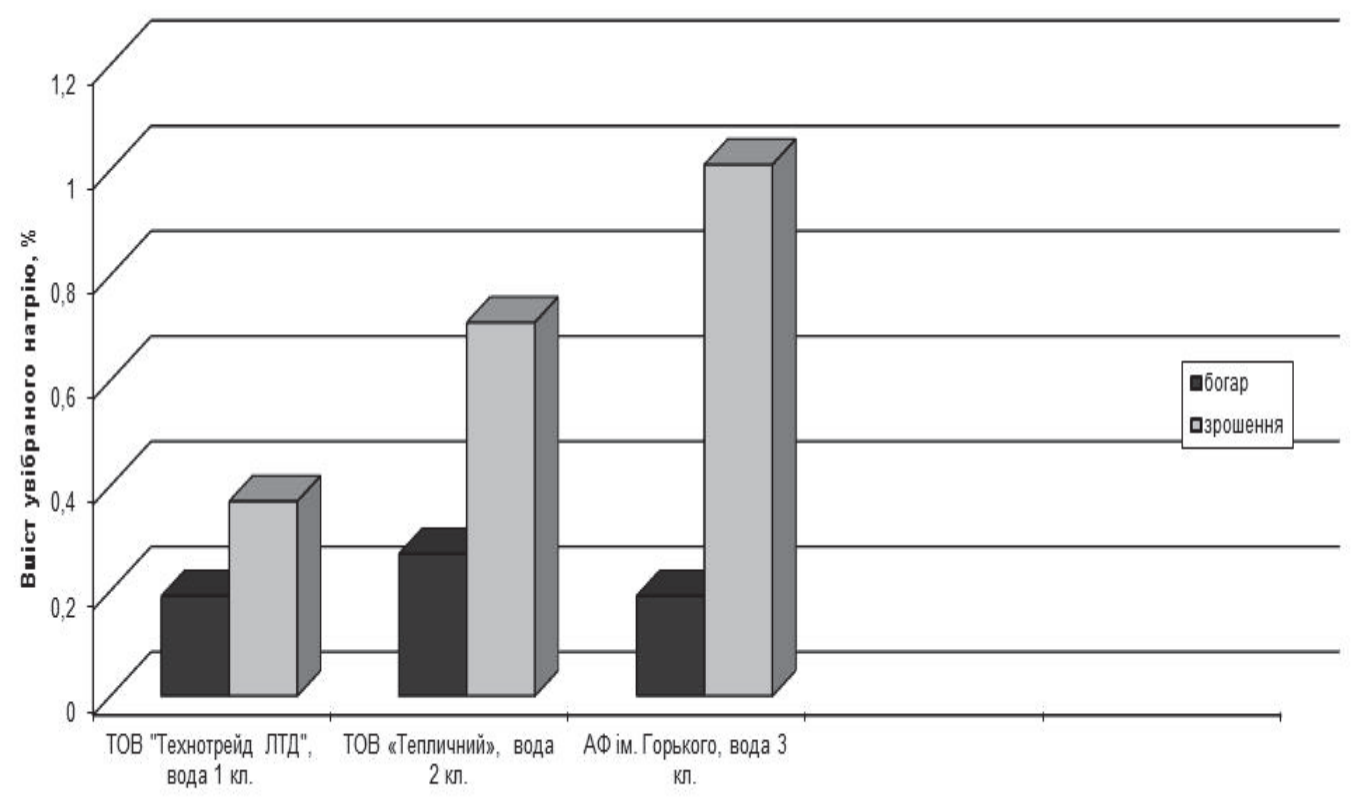

Figure 2 - The content of absorbed sodium in chernozem ordinary (0-25 cm layer)

Under irrigation with unsuitable water of the danger of soil alkalinity the share of absorbed sodium and magnesium in $0-30$ layer increases from $0.4 \%$ to $2.4 \%$ and from $18 \%$ to $24 \%$ respectively, while calcium decreases from $80 \%$ to $71 \%$. The content of cations in the top layer rises to $4.5 \%$ from the cations with the tendency to increase capacity of solonetzic horizon deep into the profile of the soil.

Changes in SAC of studied soils are caused by increased activity of sodium and decreased activity of calcium ions in the soil solution, especially in the arable layer of soil, irrigated by unsuitable water.

Unirrigated soil by activity of calcium ions was characterized as medium buffer to the alkalinity $(7,5-7,9$ $\mathrm{mEq} / \mathrm{L}$ ), as a result of long-term irrigation with water of class 3 its buffering decreased to a low degree [9] through increased activity of sodium ions $(0,85 \mathrm{mEq} / \mathrm{L}$ to $4.36 \mathrm{mEq} / \mathrm{L})$ and decreasing calcium ions to $4.73 \mathrm{mEq} / \mathrm{L}$.

By humus content in arable layer (according to DSTU 4362) studied soils are classified as low humus $(4,2-4,7 \%)$. In Agro Firm named after Gorky under growing in vegetable crop rotations of perennial grasses it is marked a tendency to slight increase of humus content in the irrigated soil compared to the unirrigated analogue. In irrigated soils of other research objects it is observed a slight decrease in humus content, due to the predominance of the processes of mineralization of organic substances, saturation of crop rotation with cultivated crops, the application of low doses of mineral fertilizers.

Long-term irrigation, especially limited suitable and unsuitable waters, due to changes of agrophysical, physico-chemical properties of chernozem ordinary leads to agrophysical degradation - compaction, destructurization, soil sealing, reduction of agronomically valuable aggregates [4].

Research has established that under irrigation with suitable water (LLC "Technotrade LTD") the density of topsoil $(0-25 \mathrm{~cm})$ of irrigated soil was optimal and significantly lower than unirrigated analogue, due to the inter-row cultivation, soil tillage by growing corn grain (Fig. 3). In the subsoil layer of irrigated soil this indicator significantly increases that may be associated with the formation of dense plow sole. Under long-term irrigation with unsuitable water from Kurakhivske reservoir (AF named after Gorky) due to more intense alkalinity of subsoil layer $(20-39 \mathrm{~cm})$ it is marked increase in the density of the soil from $1.23 \mathrm{~g} / \mathrm{cm}^{3}$ to $1.43 \mathrm{~g} / \mathrm{cm}^{3}$, which leads to deterioration of soil properties.

The mineralogical composition is an important indicator of soil fertility. Research has established that during 45-50 years of irrigation with suitable water there is a slight increase in content of montmorillonite (from $16 \%$ to $24 \%$ ) and mixed-layered formations (illite connections from $16 \%$ to $19.5 \%$, chlorite). Longterm irrigation with unsuitable water leads to activation of structural and mineralogical processes aimed at 
reducing in content of finely dispersed soil part content of hydromicaceous minerals and growth of montmorillonite. Irrigated soils are characterized by a high content of kaolinite - about 32-33\%.

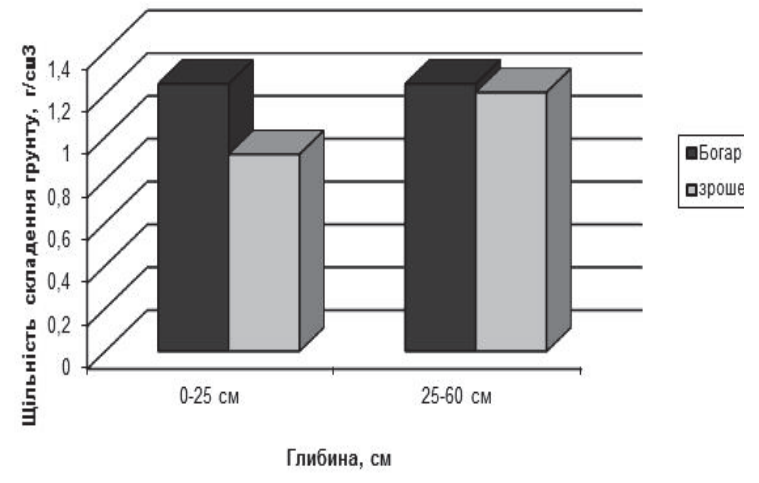

a) Irrigation with water of class 1

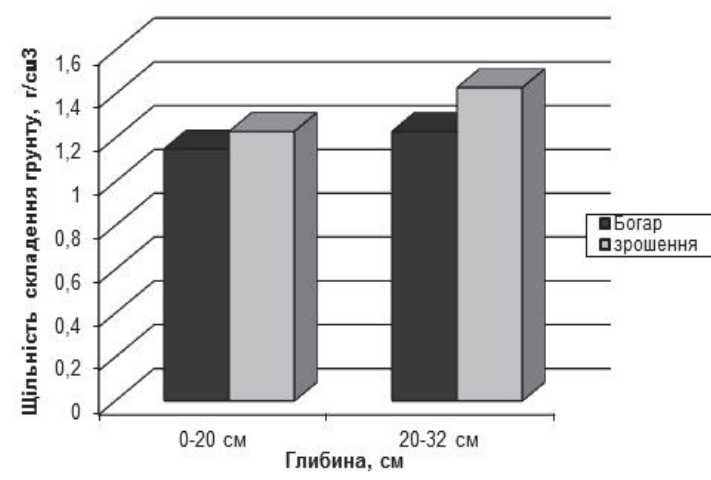

b) Irrigation with water of class 3

Figure 3 - Density of soil under irrigation with water of varying quality

Analysis of the particle size distribution of the studied soils has showed that under irrigation with suitable water (LLC "Technotrade LTD") there is no sagnificant change in the content of physical clay (61$68 \%$ ) and the soil is characterized as low clay. But in the fractional part it is marked a slight increase (by $1.5-2.0 \%$ ) of content medium, fine dust and silt fraction by the profile of soil and sand content decreases from $5.5 \%$ to $3.3 \%$.

Under long-term irrigation with unsuitable water the changes are more significant. There was worsening of size distribution from hard loamy to light loamy with increasing physical clay content from $56-59 \%$ to $65-67 \%$ due processes internally soil gleying or weathering, causing the destruction of larger particles of primary minerals (sand, medium and large dust) and transformation of them into small dust and mud.

There is a tendency to increase the content of silt fraction to $46 \%$, medium and fine dust respectively to $12-16 \%$. Dispersion factor by Kachynsky characterizing the degree of destruction of microaggregates, by irrigation with water of this quality increases from 7.4 (unirrigated soil) to 12.3, indicating a decrease in the stability of microstructure of chernozem ordinary. Structuring factor by Fehelyar that determines water resistance of units decreases from $93 \%$ to $88 \%$ due to reduction of waterproof units.

\section{Conclusions.}

As a result of monitoring research it was determined the impact of irrigation with waters of different quality (suitable, limited suitable and unsuitable) on orientation of soil processes and transformation of soil properties in chernozem ordinary of northern Steppe of Ukraine. Under long-term irrigation with limited suitable and unsuitable water changes have degrading character that appears in strengthening processes of salinity, alkalinity, compaction, worsening size distribution, reducing stability of microstructure and content of water resistance units. Obtained data is the basis for the development of predictive models of soil evolution and implementation of complex measures to protect and increase soil fertility in terms of enhanced anthropogenic load.

\section{Bibliography}

1. The concept of restoration and development of irrigation in the southern region of Ukraine / Ed. by M.I. Romashchenko. - K., 2014. - 27 p. 
2. Kovalenko P.I. Actual problems of using water and reclaimed land at the present stage // Reclamation and water management. - 2011. - Vol. 99.- P. 5-16.

3. James I.T. Soil, water and yield relationships in developing strategies /I. T. James, R.J. Godwin//Biosestems Engineering. - 2003. - Vol. 84 (4). - P. 467-480.

4. Scientific basis for the protection and rational use of the irrigated lands of Ukraine/ Ed. by S.A. Baliuk, M.I. Romashchenko, V.A. Stashuk. - K.: Agricultural Science, 2009. - 624 p.

5. Bilanchyn Ja.M. Trends and patterns of processes of modern change of chernozem of irrigation arrays of south-west of Ukraine // Bulletin of the Odessa National University. -2004. - Volume 9 - Issue 4. - P. 7-13.

6. Agroecological concept of chernozem irrigation / Ed. by P.I. Kovalenko, S.A. Baliuk, V.V. Lelyavsky. - Kharkiv, 1997. - 82 p.

7. Baliuk S.A., Nosonenko O.A. Classification of irrigated soils of Ukraine on the degree of salinity and alkalinity// Soil Science. - 2008. - V. 9. - № 3-4. - P. 27-32.

8. Baliuk S.A., Romashchenko M.I. Scientific aspects of sustainable development of lands in Ukraine. - K., 2006. - 32 p.

9. Instructions for conducting soil-salt surveys on irrigated lands of Ukraine: VND 33-5.5-11-02. - K .: Derzchvodgosp of Ukraine, 2002. - 40 p.

10. The quality of natural water for irrigation. Agronomic criteria: DSTU 2730-94. - [Valid from 01.07.1995]. - K .: State Standard of Ukraine, 1994. - 14 p.

11. Water quality for irrigation. Environmental criteria: DSTU 7286: 2012. - [Valid from 01.07.2013]. - K $\therefore$ Ministery of Economic Development of Ukraine, 2013. - 14 p. 